\title{
A possible role of an interaction of the age at common childhood infections and selected dietary factors at young age, for the later risk of multiple sclerosis
}

\author{
Klaus Lauer ${ }^{*}$, Annette Wahl ${ }^{2}$ and Marcel Geilenkeuser ${ }^{3}$ \\ ${ }^{1}$ Neuroepidemiologist, D-64347 Griesheim, Germany \\ ${ }^{2}$ Neurologist, Neurologicum Darmstadt, Germany \\ ${ }^{3}$ Neurologist, Neurologische Gemeinschaftspraxis, Ober-Ramstadt, Germany
}

\begin{abstract}
An increased risk of multiple sclerosis (MS) had been found when individuals had consumed large amounts of processed meat and scalded sausages in childhood and adolescence. Furthermore, it was found in many studies that MS patients had acquired one or another common childhood infection at higher ages than controls. As a consequence, MS patients from an epidemiological long - term investigation in Germany, and two different hospital control groups, were analysed for a statistical interaction of these two factors. $324 \mathrm{MS}$ patients and 242 hospital controls from an epidemiological long - term investigation was inquired. The study focussed on age up to 16 years. Individuals were tested for additive interaction by multiple linear regression analysis. There was an additive interaction of a higher age at one or another common childhood infection and the consumption of sausages cured with nitrate or nitrite, and were additionally hot - smoked at $>50^{\circ} \mathrm{C}$ (regression estimate $=0.1370$; standard error $=0.0603 ; p=0.0239)$. In contrast, no such an interaction could be demonstrated for: animal fats; smoked meat (e.g. ham and bacon); and cold - smoked (German) salami. In conclusion, there was a synergy of the intake of scalded sausages (e.g. frankfurters, bolognas, etc.) and the age at common childhood infections, for the risk of MS later in life.
\end{abstract}

\section{Introduction}

Multiple sclerosis (MS) is a chronic, inflammatory disease of the human central nervous system (CNS) with many autoimmune characteristics. The disease typically starts at age $15-50$ years, and the clinical course is quite variable. In many patients, it leads to a permanent neurologic disability [1]. The multifactorial aetiology of the disease includes a variety of genetic factors, particularly those involved in immune functions [2-4], but the bulk of the overall risk (ca. $70 \%$ ) is caused by environmental factors $[5,6]$. Epidemiological research of the past 30 years has revealed some items which bear an increased risk of MS, e.g. late infection with Epstein-Barr virus (EBV) [7], deficiency of vitamin D [8-10], tobacco smoking [10], and dietary factors as insufficient amounts of vegetables and fruit [11-13], rareness of fish and seafood $[12,14]$, and high intake of processed meat $[15,16]$. However, conclusions on the definite role of all these factors and their causal pathway cannot yet be drawn. In particular, an inconsistency of the wide distribution of these factors in the normal population of Western countries on one hand, and the rather exceptional occurrence of MS on the other, make them unlikely to play an isolated role. An interaction, however, with other genetic and / or other environmental factors is possible.

The type of interaction, i.e. multiplicative or additive, in epidemiological studies is a matter of debate [17 - 24]. Recent reports argued much in favour of additive models when public health issues are concerned [20-24]. In case - control investigations, we [25,26] and many others [e.g. 27 - 29] reported a higher risk of MS, if one or another type of infection typically occurring in early life (e.g. measles; rubella; pertussis; chickenpox; and infectious mononucleosis), were acquired later in childhood, in adolescence, or even in adulthood. Another risk factor in the causality of MS was the intake of processed meat, particularly of scalded sausages (e.g. frankfurters and bolognas) $[15,16]$. For preservation, these sausages are processed by curing with nitrites and subsequently smoked at higher temperatures $\left(>50^{\circ} \mathrm{C}\right)$. In the present study, the data pool of the epidemiological long - term investigation of MS in Southern Hesse, Germany [25,26], and of two subsequent case - control investigations [30,31] were analysed. These two studies used the same pool of MS patients, but two different kinds of hospital controls. The age when childhood infections occurred, and several food variables were tested for an additive interaction at age 0 -16 for the risk of MS later in life $[20,23,24]$. Childhood was focused, because important risk factors occur at this early age [32 - 34].

\section{Methods}

Data of 324 patients with definite or probable MS (230 females, 94 males) according to Bauer's criteria [35] from Southern Hesse, Germany $[25,26,36]$ were included in the present study. All patients had two or more attacks or a primary progressive course of MS. The mean year of birth (YOB) of the MS patients was 1948 (SD: 13.1 years; range 1913 - 1974). The epidemiological study, was done during 1985 - 1998,

Correspondence to: Klaus Lauer MD, Assistant Professor, Eulerweg 4, D-64347 Griesheim, Germany, Tel: +49 - (0) - 6155 -608899; E-mail: drklauslauer@aol.com

Key words: multiple sclerosis; epidemiology; diet; childhood infections; interaction

Received: November 05, 2017; Accepted: November 20, 2017; Published: November 23, 2017 
Lauer K (2017) A possible role of an interaction of the age at common childhood infections and selected dietary factors at young age, for the later risk of multiple sclerosis

including questioning of all MS patients on their diet in childhood and early adolescence. 242 hospital controls (139 females; 103 males) were collected in three phases: (a) 41 patients with lumbar disc herniation, or other types of orthopaedic low - back pain, were interrogated by K.L. with an identical questionnaire as the MS patients from 1986 - 1987 [25]; (b) a second group $(n=99)$ with the same orthopaedic diagnoses were interrogated by A.W., as part of her doctoral thesis, in 1994 - 1996 [30]; and (c) a third group $(n=102)$ which had been treated with varying minor surgeries (e.g. appendectomy; herniotomy; cholecystectomy; etc.), were interrogated by M.G. at the Department of Surgery of the Elisabethenstift Hospital in Darmstadt, Germany, as part of another doctoral thesis in 1997 - 1998; patients with a severe general condition and all cancer cases were excluded from the latter group [31]. The mean YOB of all the hospital controls $(n=242)$ was 1949 (SD: 13.8 years; range 1912 - 1978).

MS patients and hospital controls were personally interviewed by one of the authors, with a questionnaire that had identical questions on the study variables. Childhood infectious diseases were interrogated with the possible answers "yes" or "no" and, if "yes", the age was questioned when the respective disease (measles; chickenpox; rubella; whooping cough; infectious mononucleosis in part of the interviewees) had occurred ( 0 - 5 years; $6-9$ years; $10+$ years). "Any childhood infection with manifestation at age $0-5$ (score 0 ) vs. $6+$ years (score 1)" was taken as the first exposure. The following food variables were interrogated: "intake of animal fat"; and ingestion of: "smoked meat (ham; bacon)"; "cold - smoked (German) salami"; and "scalded sausages". All food items were originally asked by means of a food frequency questionnaire (FFQ) with four ordered categories, which were finally dichotomized to "at least once per week" vs. "more rarely". All subjects gave their informed consent for inclusion. The study was conducted in accordance with the Declaration of Helsinki.

Additive interaction was tested by the standard procedure of multiple linear regression [20,23]. The model included, altogether, the intake of: "animal fat", "smoked meat", "cold - smoked salami", and a product term of "scalded sausages and age 6+ at any childhood disease" ("yes" = score 1; "no" = score 0). The statistical software (German) Statistica for the Windows ${ }^{\mathrm{TM}}$ [37] was used for all calculations.

\section{Results}

There was no difference of the YOB between MS cases and hospital controls (Student's $t=0.0691$; not significant). The sex distribution of the MS cases showed a higher number of females than in the hospital control group (fourfold - table test: $\mathrm{chi}^{2}=11.21 ; \mathrm{p}=0.0008$ ).

For testing for collinearity of the independent variables, a correlation analysis by Spearman's rho was made, after stratification in MS patients and hospital controls. In controls, there was a borderline correlation between "scalded sausages" and "cold - smoked (German) salami". A correlation was also found between "cold - smoked (German) salami" and "smoked meat". No association occurred between "scalded sausages" and "animal fat" (Table 1).

In MS patients, there was a highly significant correlation between "cold - smoked (German) salami" and "scalded sausages", and between "animal fat" and "smoked meat". No correlation of "smoked meat" with "cold - smoked (German) salami" was found, and even a reversed borderline association of "scalded sausages" with the intake of "animal fat" was shown (Table 2).

For testing a role of single dietary variables on the risk of MS, these factors were individually included into logistic models, with adjustment
Table 1. Rank correlation of independent variables in hospital controls. n.s. = not significant $(\mathrm{p}>0.10){ }^{*}=$ correlated with.

\begin{tabular}{|c|c|c|c|}
\hline variables & no. & Spearman's rho & $\boldsymbol{p}$ - level \\
\hline $\begin{array}{c}\text { animal fat } * \\
\text { German salami }\end{array}$ & 139 & -0.0321 & n.s. \\
\hline $\begin{array}{c}\text { animal fat } * \\
\text { smoked meat }\end{array}$ & 140 & 0.1372 & n.s. \\
\hline $\begin{array}{c}\text { animal fat } * \\
\text { scalded sausage }\end{array}$ & 138 & 0.0341 & n.s. \\
\hline $\begin{array}{c}\text { smoked meat } \\
\text { German salami }\end{array}$ & 202 & 0.1465 & 0.0375 \\
\hline $\begin{array}{c}\text { smoked meat } \\
\text { scalded sausage }\end{array}$ & 202 & 0.1015 & n.s. \\
\hline $\begin{array}{c}\text { German salami } * \\
\text { scalded sausage }\end{array}$ & 202 & 0.1345 & 0.0563 \\
\hline
\end{tabular}

Table 2. Rank correlation of independent variables in MS cases. n.s. $=$ not significant ( $\mathrm{p}>$ $0.1)$ * correlated with.

\begin{tabular}{|c|c|c|c|}
\hline variables & no. & Spearman's rho & $p$-level \\
\hline $\begin{array}{c}\text { animal fat } * \\
\text { German salami }\end{array}$ & 268 & -0.0836 & n.s. \\
\hline $\begin{array}{c}\text { animal fat } \\
\text { smoked meat }\end{array}$ & 270 & 0.2035 & 0.0008 \\
\hline $\begin{array}{c}\text { animal fat } \\
\text { scalded sausage }\end{array}$ & 271 & -0.1012 & 0.0963 \\
\hline $\begin{array}{c}\text { smoked meat } \\
\text { German salami }\end{array}$ & 272 & 0.0423 & n.s. \\
\hline $\begin{array}{c}\text { smoked meat } \\
\text { scalded sausage }\end{array}$ & 275 & 0.1152 & 0.0563. \\
\hline $\begin{array}{c}\text { German salami } * \\
\text { scalded sausage }\end{array}$ & 273 & 0.1679 & 0.0054 \\
\hline
\end{tabular}

for sex, or unadjusted for "sex" and "smoked meat" because of high collinearity (Table 3 ). There was a significant association with "female sex"; "animal fats"; "cold - smoked (German) salami"; "smoked meat" (borderline); and "scalded sausages" (borderline) (Table 3).

To test for an interaction, age at childhood infections (age 0 - 5 vs. $6+$ years) and all of the dietary variables were included in a linear regression model. The interaction variable of "scalded sausages and late childhood infection at age 6+" was significant, whereas the interaction of all the other dietary variables with age at childhood infections were not (Table 4).

\section{Discussion}

In the present study, an additive interaction of "age at any childhood infection" and "consumption of scalded sausages at age 0 16 years" was found to be a risk factor for MS later in life. Both factors were not related to, or only borderline associated with MS, respectively, when studied individually. The findings are, all the more, remarkable as there was a considerable confounding between most dietary exposures that were tested (Tables 1 and 2). Confounding, however, should rather more diminish instead of exaggerate the Odds Ratios (38).

The term "any childhood infections", as used in the present investigation, only partly included infectious mononucleosis, which became apparent as a risk factor for MS first during our epidemiologic long - term studies. Meanwhile, infectious mononucleosis has been shown by many authors, including ourselves, to be associated with the risk of MS $[30,39,40]$, and a role of the infection with EBV was demonstrated in a meta - analysis [41]. Since infectious mononucleosis was not recorded in all patients of the present study, it was not feasible to analyse it in a proper way. A major contribution of EBV to the overall association is possible, but a higher age at infection with other, including several, neurotropic agents during childhood 
Lauer K (2017) A possible role of an interaction of the age at common childhood infections and selected dietary factors at young age, for the later risk of multiple sclerosis

Table 3. Logistic regression of food variables with MS when only sex, or no variable*, were adjusted.

\begin{tabular}{|c|c|c|c|}
\hline variables & estimate & SE & $\boldsymbol{p}$ - level \\
\hline female sex* & 0.5950 & 0.1784 & 0.0009 \\
\hline animal fats & 1.0248 & 0.2133 & $<0.0001$ \\
\hline smoked meat* & 0.3594 & 0.1919 & 0.0617 \\
\hline German salami & 0.4484 & 0.2067 & 0.0306 \\
\hline scalded sausage & 0.3568 & 0.1896 & 0.0605 \\
\hline
\end{tabular}

Table 4. Multiple linear regression model for testing additive interaction $[16,19] . \mathrm{B}=$ linear regression estimate. $\mathrm{SE}=$ standard error. $\mathrm{YOB}=$ year of birth. $\mathrm{CI}=$ childhood infection. $\mathrm{n} . \mathrm{s} .=$ not significant.

\begin{tabular}{|c|c|c|c|}
\hline Variables & B & SE & $\boldsymbol{p}$ - level \\
\hline intercept & 0.6095 & 0.1195 & $<0.0001$ \\
\hline female sex & 0.1599 & 0.0561 & 0.0046 \\
\hline YOB 1951+ & 0.1407 & 0.0562 & 0.0129 \\
\hline animal fat & 0.0465 & 0.1115 & n.s. \\
\hline smoked meat & -0.1138 & 0.1213 & n.s. \\
\hline German salami & 0.1062 & 0.1076 & n.s. \\
\hline scalded sausage & 0.0031 & 0.0045 & n.s. \\
\hline any CI at age 6+ & -0.2302 & 0.1266 & 0.0699 \\
\hline $\begin{array}{c}\text { "animal fat" + "any } \\
\text { CI at age 6+" }\end{array}$ & 0.1317 & 0.1233 & n.s. \\
\hline $\begin{array}{c}\text { "smoked meat" + } \\
\text { "any CI at age 6+" }\end{array}$ & 0.1045 & 0.1356 & n.s. \\
\hline $\begin{array}{c}\text { "German salami"+ } \\
\text { "any CI at age 6+" }\end{array}$ & 0.0771 & 0.1251 & 0.0239 \\
\hline $\begin{array}{l}\text { "scalded sausage" + } \\
\text { "any CI at age 6+" }\end{array}$ & 0.1370 & 0.0603 & \\
\hline
\end{tabular}

and adolescence might be another explanation. Our data agree with ecological studies in 16 regions which showed a risk of processed meat for MS later in life $[15,16,42,43]$. Furthermore, there was a considerable limitation in the time frame when both risk factors occur together in one individual. Thus, it is prudent to advise young patients with any infectious disease, including those with only minor symptoms such as cough, fever and malaise, to abstain from all scalded sausages during symptomatic infection and a rather short period of recovery.

In accordance with the literature, the present data suggest the following hypothetical scenario: a young individual (e.g. at age 5 $15[33,34])$ has acquired one or another infectious disease caused by some neurotropic agent. This is a very common event. In a very limited period of the infection, the individual has a leakage of both the mucosal barrier in the gut [44] and of the blood - brain barrier $[45,46]$ due to that infection. In the great majority of cases, central nervous system (CNS) inflammation, though common, is clinically not apparent although a disruption of the blood - brain barrier is present in a high number of cases [45]. Only when, in this critical period of both leaky barriers, scalded sausages are presented to the individual, an autoimmune process is started which involves the CNS, because also the $\mathrm{BBB}$ is damaged at that time. Nitro - phenylated carrier conjugates which are formed in smoked and nitrite - cured meat products [47], may play a critical role. It is even possible that a compound of animal myelin (e.g. myelin basic protein; proteolipid protein; myelin oligodendrocyte glycoprotein) present in the meat [48], might act as a carrier for the nitro - phenylated haptens. In that way, the situation may be comparable to experimental animals which develop an autoimmune disease of the thyroid, when they are treated with nitro - phenolic thyroglobulin [49]. The nitro - phenol conjugates in the meat [47] may be considered "amplifiers" towards an autoimmune status of the individual. In fact, animal proteolipid protein, a specific marker of CNS tissue which is commonly used in the diagnosis of bovine spongiform encephalitis (BSE), was present in a high number of sausage types sold on the market in southern Germany, where this brain material of animal origin had been added by manufacturers due to its good emulsifying property at low cost [48].

The long exposure time in the present study may argue for additional factors than nitrophenol haptens, which are present in the meat product. For example, in many countries, sausages contain whole milk or milk powder [50,51]. In Germany, however, milk is not permitted in sausage fabrication (with very few exceptions) [52]. Furthermore, there was no evidence for milk consumption as a risk factor for MS in our case - control studies [30,31]. Thus, e.g. the hypothesis of a role of milk butyrophilin that was shown to cross - react with epitopes of myelin oligodendrocyte glycoprotein (MOG) [53], is not supported by the present data.

It seems very likely that the formation of clinical autoimmunity takes months, or even years. The time, however, until the start of a symptomatic autoimmune disease might be considerably shortened, and the clinical disease aggravated, when the same scenario occurs repeatedly in time in one individual, with either the same or different infectious agent(s).

It should be clearly stated that a reduction of the severity of MS by other dietary measures (e.g. increased intake of: n6 - polyunsaturated fatty acids as vegetable oils [54]; polyphenols from vegetables and fruits $[12,55]$; and $\mathrm{n} 3$ - polyunsaturated fatty acids from fish and seafood [5659]), are not referred to by the present data. They should be studied also more in detail.

In conclusion, there was a significant interaction between the age at any childhood infection and the consumption of scalded sausages at the age up to 16 years, for the risk of MS later in life. Further investigations to corroborate the findings in other populations, and studies of population controls, are warranted.

\section{Acknowledgement}

The results were partly presented at the Congress of the European Academy of Neurology (EAN), Copenhagen, Denmark, May 28 - 31, 2016

\section{Conflict of interest}

The authors declare no conflict of interest.

\section{Authors Contribution}

K.L. interrogated all MS patients and part of the hospital controls. He made all statistical calculations, and wrote the paper. A.W. and M.G. interrogated the other hospital controls.

\section{References}

1. Compston DAS, Confavreux C, Lassmann H, McDonald I, Miller D, Noseworthy J, Smith K, Wekerle H (2006) McAlpine's multiple sclerosis, 4th edition; Churchill Livingstone - Elsevier: Philadelphia PA, USA.

2. Sawcer S, Franklin RJ, Ban M3 (2014) Multiple sclerosis genetics. Lancet Neurol 13 700-709. [Crossref]

3. Bashinskaya VV, Kulakova OG, Boyko AN, Favorov AV, Favorova OO (2015) A review of genome - wide association studies for multiple sclerosis: classical and hypothesis - driven approaches. Hum Genet 134: 1143 - 1162. [Crossref]

4. Wang Z, Sadovnick AD, Traboulsee AL3, Ross JP4, Bernales CQ4, et al. (2016) Nuclear Receptor NR1H3 in familial multiple sclerosis. Neuron 90: 948 - 954. [Crossref]

5. Ebers GC, Bulman DE, Sadovnick AD, Paty DW, Warren S, et al. (1986) A populationbased study of multiple sclerosis in twins. $N$ Engl J Med 315: 1638-1642. [Crossref] 
Lauer K (2017) A possible role of an interaction of the age at common childhood infections and selected dietary factors at young age, for the later risk of multiple sclerosis

6. Mumford CJ, Wood NW, Kellar-Wood H, Thorpe JW, Miller DH, et al. (1994) The British Isles survey of multiple sclerosis in twins. Neurology 44: 11 - 15. [Crossref]

7. Almohmeed YH, Avenell A, Aucott L, Vickers MA (2013) Systematic review and meta-analysis of the sero-epidemiological association between Epstein-Barr virus and multiple sclerosis. PLosOne 8: e 61110. [Crossref]

8. Ascherio A, Munger KL, Simon KC (2010) Vitamin D and multiple sclerosis. Lancet Neurol 9: 599 - 612. [Crossref]

9. Berlanga-Taylor AJ, Ramagopalan SV (2013) Vitamin D and multiple sclerosis: what is the clinical impact? Expert Opin Med Diagn 7: 227 - 229. [Crossref]

10. Ascherio A, Munger KL, Lünemann JD (2012) The initiation and prevention of multiple sclerosis. Nat Rev Neurol 8: 602 - 612. [Crossref]

11. Lauer K (1994) The risk of multiple sclerosis in the U.S.A. in relation to sociogeographic features: a factor-analytic study. J Clin Epidemiol 47: 43 - 48. [Crossref]

12. Ghadirian P, Jain M, Ducic S, Shatenstein B, Morisset R (1998) Nutritional factors in the aetiology of multiple sclerosis: a case-control study in Montreal, Canada. Int J Epidemiol 27: 845 - 852. [Crossref]

13. Wender M, Kazmierski R (1994) The descriptive and analytical epidemiology of multiple sclerosis in Western Poland. In: Firnhaber W, Lauer K (eds) Multiple sclerosis in Europe. An epidemiological update. Alsbach - Bergstrasse, Germany: LTV Press, pp. $241-248$

14. Kampman MT, Wilsgaard T, Mellgren SI (2007) Outdoor activities and diet in childhood and adolescence relate to MS risk above the Arctic Circle. J Neurol 254: 471 - 477. [Crossref]

15. Lauer K (2011) Dietary exposures and multiple sclerosis: a review. Rev Esp Esclér Múlt 19: 13 - 21

16. Lauer K (2014) Notes on the epidemiology of multiple sclerosis, with special reference to dietary habits. Int J Mol Sci 15: 3533 - 3545. [Crossref]

17. Greenland S (1983) Tests for interaction in epidemiologic studies: a review and a study of power. Stat Med 2: 243 - 251. [Crossref]

18. Walker AM (1981) Proportion of disease attributable to the combined effect of two factors. Int J Epidemiol 10: 81 - 85. [Crossref]

19. Rothman KJ, Greenland S, Walker AM (1980) Concepts of interaction. Am Epidemiol 112: 467 - 470. [Crossref]

20. Knol MJ, VanderWeele TJ, Groenwold RH, Klungel OH, Rovers MM, et al. (2011) Estimating measures of interaction on an additive scale for preventive exposures. Eur J Epidemiol 26: 433 - 438. [Crossref]

21. Andersson T, Alfredsson L, Källberg H, Zdravkovic S, Ahlbom A (2005) Calculating measures of biological interaction. Eur J Epidemiol 20: 575 - 579. [Crossref]

22. Ahlbom A, Alfredsson L (2005) Interaction: a word with two meanings creates confusion. Eur J Epidemiol 20: 563 - 564. [Crossref]

23. Knol MJ, van der Tweel I, Grobbee DE, Numans ME, Geerlings MI (2007) Estimating interaction on an additive scale between continuous determinants in a logistic regression model. Int J Epidemiol 36: 1111 - 1118. [Crossref]

24. Rothman KJ (2002) Epidemiology: an introduction. New York: Oxford University Press.

25. Lauer K (1993) Deskriptive und analytische Untersuchungen zur Epidemiologie de multiplen Sklerose im Raum Südhessen. Thesis. Johann Wolfgang Goethe - University, Frankfurt, Germany (in German).

26. Lauer K, Firnhaber W (1994) Descriptive and analytical epidemiological data on multiple sclerosis from a long - term study in Southern Hesse, Germany. In: Firnhaber W, Lauer K, eds.: Multiple sclerosis in Europe. An epidemiological update. Alsbach Bergstrasse, Germany: LTV Press, pp. 147 - 158

27. Grønning M, Riise T, Kvåle G, Albrektsen G, Midgard R, Nyland H (1993) Infections in childhood and adolescence in multiple sclerosis. Neuroepidemiology 12: 61 - 69.

28. Hays P (1992) Multiple sclerosis and delayed mumps. Acta Neurol Scand 85: 200 - 203.

29. Casetta I, Granieri E, Malagu S, et al. (1994) Environmental risk factors and multiple sclerosis: a community - based study in the province of Ferrara, Italy. Neuroepidemiology 13: 120 - 128 .

30. Wahl A (2002) Die Suche nach exogenen Risikofaktoren bei multipler Sklerose: eine Fall - Kontroll - Studie. Medical Dissertation. Johann Wolfgang Goethe - University Frankfurt, Germany (in German).
31. Geilenkeuser M (2004) Risikofaktoren der multiplen Sklerose: Ergebnisse einer Fall - Kontroll - Studie. Medical Dissertation. Johann Wolfgang Goethe - University, Frankfurt, Germany (in German).

32. Kurtzke JF (1985) Epidemiology of multiple sclerosis. In: Koetsier JC, ed. Handbook of clinical neurology, vol.3 (47). Amsterdam, The Netherlands: Elsevier, pp. 259 - 287.

33. Dean G, Kurtzke JF (1971). On the risk of multiple sclerosis according to age at immigration to South Africa. Br Med J 3: 725 - 729.

34. Alter M, Okihiro M (1971) When is multiple sclerosis acquired? Neurology 21: 1030 $-1036$.

35. Bauer HJ (1972) Communication to: Judgement of the validity of a clinical MS diagnosis. Acta Neurol Scand 50 (Suppl.58): 71 - 74.

36. Lauer K, Firnhaber W, Reining R, Leuchtweis B (1984) Epidemiological investigations into multiple sclerosis in Southern Hesse. I. Methodological problems and basic epidemiological characteristics. Acta Neurol Scand 70: 257 - 265. [Crossref]

37. StatSoft (1994) Statistica for the Windows ${ }^{\mathrm{TM}}$. Tulsa OK, USA: StatSoft Inc.

38. Hennekens CH, Buring JE, Mayrent SL (1987) Epidemiology in medicine. Boston MA, USA: Little, Brown and Cy.

39. Handel AE, Williamson AJ, Disanto G, Handunnetthi L, Giovannoni G, et al. (2010) An updated meta - analysis of risk of multiple sclerosis following infectious mononucleosis. PLosOne 5: e12496. [Crossref]

40. Zaadstra BM, Chorus AM, van Buuren S, Kalsbeek H, van Noort JM (2008) Selective association of multiple sclerosis with infectious mononucleosis. Mult Scler 14: 307 . 313. [Crossref]

41. Thacker EL, Mirzaei F, Ascherio A (2006) Infectious mononucleosis and risk for multiple sclerosis: a meta-analysis. Ann Neurol 59: 499 - 503. [Crossref]

42. Lauer K (2014) Multiple sclerosis prevalence and the production of smoked sausages in Iran: an exploratory ecological study. Neuroepidemiology 43: 87. [Crossref]

43. Lauer KJ (2015) Multiple sclerosis: socio - economic factors and food habits in Tehran, Iran. Ann Nutrition Metabolism 67 (Suppl.1): 325.

44. Sanderson IR, Walker WA (1993) Uptake and transport of macromolecules by the intestine: possible role in clinical disorders (an update). Gastroenterology 104: 622639. [Crossref]

45. Pejme J (1964) Infectious mononucleosis. A clinical and haematological study of patients and contacts, and a comparison with healthy subjects. Acta Med Scand 175 (Suppl. 413): 1 - 83 .

46. Sheehy TW, Artenstein MS, Green RW (1964) Small intestinal mucosa in certain viral diseases. JAMA 190: 1023 - 1028. [Crossref]

47. Knowles ME, Gilbert J, MacWeeny DJ (1975) Phenols in smoked, cured meats nitrosation of phenols in liquid smokes and in smoked bacon. J Sci Food Agric 26 267 - 276. [Crossref]

48. Weigelt I, Schulze G, Pischetsrieder M (2010) Immunochemical detection of tissue from the central nervous system via myelin proteolipid protein: adaptation for food inspection and development of recombinant bivalent Fab mini - antibodies. $J$ Agricul Food Chem 58: 6587 - 6593. [Crossref]

49. Weigle WO (1965) The induction of autoimmunity in rabbits following injection of heterologous or altered homologous thyroglobulin. J Exp Med 121: 289 - 308 [Crossref]

50. Pearson AM, Tauber FW (1984) Processed meats. Westport CT, USA: AVI Publication

51. Romans JR, Jones KW, Costello WJ, Carlson CW, Ziegler PD (1977) The meat we eat. Denville IL, USA: Interstate Printers and Publishers.

52. Anonymus. Verordnung über Fleisch und Fleischerzeugnisse (Fleisch-Verordnung) vom 19. Dezember 1959. Bundesgesetzblatt 1959, Teil I, 726 - 729 (in German)

53. Stefferl A, Schubart A, Storch M (2000) Butyrophylin, a milk protein, modulates the encephalitogenic $\mathrm{T}$ cell response to myelin oligodendrocyte glycoprotein in experimental autoimmune encephalomyelitis. J Immunol 165: 2859 - 2865. [Crossref]

54. Dworkin RH, Bates D, Millar JH, Paty DW (1984) Linoleic acid and multiple sclerosis: a reanalysis of three double-blind trials. Neurology 34: 1441 - 1445. [Crossref]

55. Hadgkiss EJ, Jelinek GA, Weiland TJ, Pereira NG, Marck CH, et al. (2015) The association of diet with quality of life, disability, and relapse rate in an international sample of people with multiple sclerosis. Nutr Neurosci 18: 125 - 136. [Crossref] 
Lauer K (2017) A possible role of an interaction of the age at common childhood infections and selected dietary factors at young age, for the later risk of multiple sclerosis

56. Nordvik I, Myhr KM, Nyland H, Bjerve KS (2000) Effect of dietary advice and n-3 supplementation in newly diagnosed MS patients. Acta Neurol Scand 102: 143 - 149. [Crossref]

57. D'hooghe MB, Haentjens P, Nagels G, De Keyser J (2012) Alcohol, coffee, fish, smoking and disease progression in multiple sclerosis. Eur J Neurol 19: 616 - 624. [Crossref]
58. Jelinek GA, Hadgkiss EJ, Weiland TJ, Pereira NG, Marck CH, et al. (2013) Association of fish consumption and omega 3 supplementation with quality of life, disability and disease activity in an international cohort of people with multiple sclerosis. Int $J$ Neurosci 123: 792 - 800. [Crossref]

59. Hoare S, Lithander F, van der Mei I, Ponsonby A-L, Lucas R (2016) Higher intake of omega-3 polyunsaturated fatty acids is associated with a decreased risk of a first clinical diagnosis of central nervous system demyelination: results from the Ausimmune Study. Mult Scl J 22: 884 - 892. [Crossref]

Copyright: (C2017 Lauer K. This is an open-access article distributed under the terms of the Creative Commons Attribution License, which permits unrestricted use, distribution, and reproduction in any medium, provided the original author and source are credited. 